\title{
High Energy Efficiency Air Conditioning
}

\author{
Final Report \\ Non-confidential - for public release
}

Edward McCullough, Patrick Dhooge, and Jonathan Nimitz

Nimitz, Inc. dba Environmental Technology \& Engineering Center (ETEC) 4500 Hawkins St. NE Suite B

Albuquerque, NM 87109-4541

December 2003

PREPARED FOR THE UNITED STATES

DEPARTMENT OF ENERGY

Under Grant No. DE-FG36-02G012067 
High Energy Efficiency Air Conditioning

\section{Disclaimer}

Issued by the Environmental Technology and Engineering Center (ETEC)

This report was prepared as an account of work performed at ETEC. Neither ETEC nor any agency thereof, nor any of their employees, nor any of their contractors, subcontractors, or their employees, makes any warranty, expressed or implied, or assumes any legal liability or responsibility for the accuracy, completeness, usefulness of any information, apparatus, product, or process disclosed, or represents that it would not infringe privately owned rights. Reference herein to any specific commercial product, process, or service by trade name, trademark, manufacturer, or otherwise, does not necessarily constitute or imply its endorsement, recommendation, or favoring by the United States Government, or any agency thereof, or any of their contractors or subcontractors.

\section{Acknowledgements}

ETEC wishes to express our appreciation to the DOE for the opportunity to develop this promising new refrigeration technology, and for the help provided by DOE personnel including Project Officers Gibson Asuquo and Keith Bennett and Senior Project Monitor James Alkire.

ETEC would like to acknowledge the efforts of Mr. John Balsam of New Horizon Technologies, Inc. and Mr. Bill Harrington of Vista Ventures, LLC for providing valuable information and consultation on commercialization of the technology covered in this report. 


\section{Table of Contents}



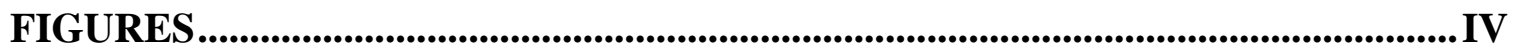

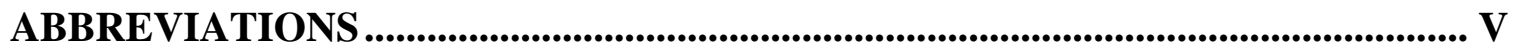

EXECUTIVE SUMMARY ……................................................................................ 1

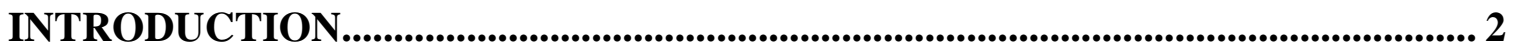

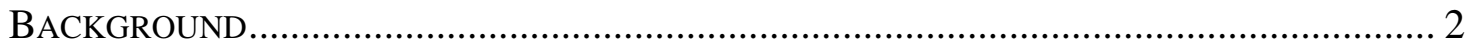

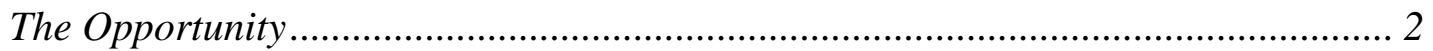

The Innovation ………………………........................................................ 2

PROJECT GOALS................................................................................................... 5

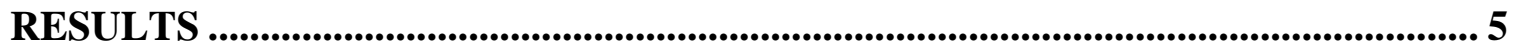

TASK 1. OBTAIN AND INSTALL AIR CONDITIONER ………………………………........ 5

Background Information................................................................................. 5



Split System Air Conditioner.................................................................................. 6

Instrumentation and Data Acquisition.................................................................. 11

Thermocouple Locations.................................................................................... 11

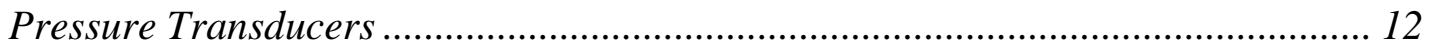

Energy Transducer......................................................................................... 16

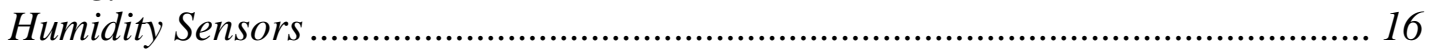

TASK 2. BASELINE AIR CONDITIONER ENERGY USE ...................................................... 16

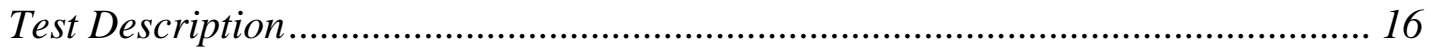

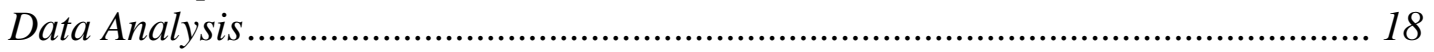

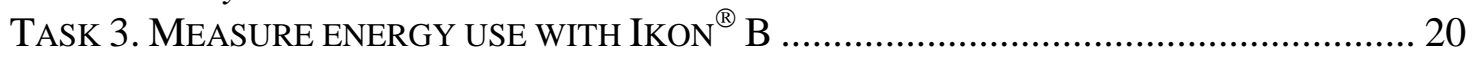

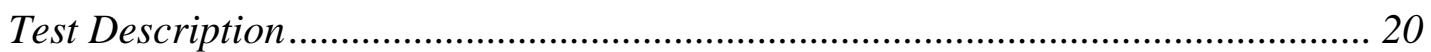

Operational Parameters and Energy Use Measurements ....................................... 20

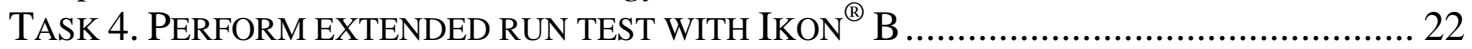

Test Description and Setup .................................................................................. 22

Extended Run Operational Parameters and Energy Use ......................................... 22

Post-Run Analysis ............................................................................................ 23

Gas Chromatograph Analysis of Ikon ${ }^{\circledR}$ B after Extended Run ................................. 28

CONCLUSIONS ............................................................................................................ 28

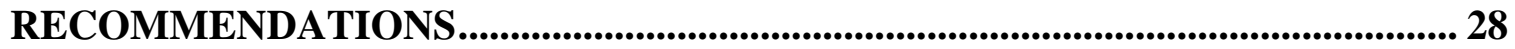




\section{High Energy Efficiency Air Conditioning}

\section{Tables}

TABle 1. COMPIlation of PeRformance Test Results For IKON ${ }^{\circledR}$ B. .4

TABLE 2. REFPROP ${ }^{\circledR} /$ COOLS SIMULATION COMPARISON OF R-22 REPLACEMENTS VERSUS R-22 IN AIR-

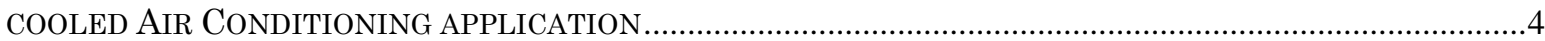

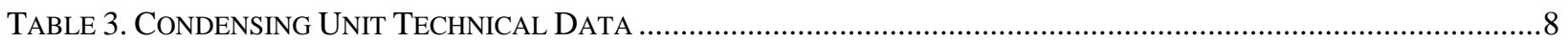

TABLE 4. EVAPORATOR / AIR HANDLING UNIT TECHNICAL DATA..........................................................................

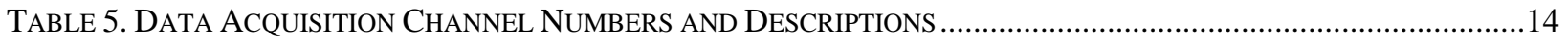

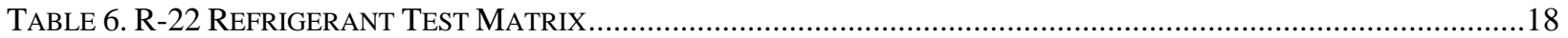

TABLE 7. SAMPLE ENERGY BALANCE WORKSHEET FOR ENERGY USE TESTS ..................................................19

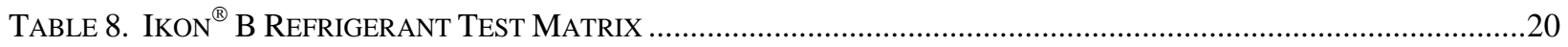

TABle 9. Final Results for ENERgy USE of the Residential Split SyStem Air Conditioner Charged With R-22 OR IKON ${ }^{\circledR}$ B. .21

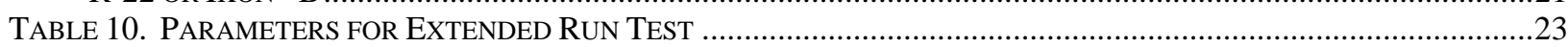

\section{Figures}

FIGURE 1. ENVIRONMENTAL CHAMBER AND EXPERIMENTAL SETUP ...................................................................

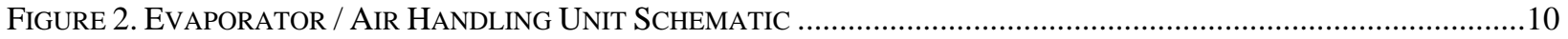

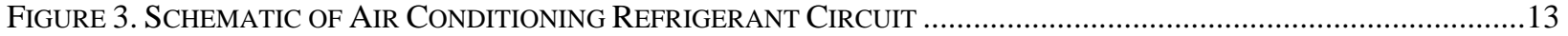

FIGURE 4. TOP VIEW OF CONDENSING UNIT WITH THERMOCOUPLES LOCATIONS ...................................................15

FIGURE 5. SIDE VIEW OF CONDENSING UNIT (SCANNED FROM PRODUCT LITERATURE) ..........................................15

Figure 6. Plot of COMPRESSOR ENERGy USAGE FOR THE EXTENDED Run TEST (TRENDLINE IN RED) ...................26

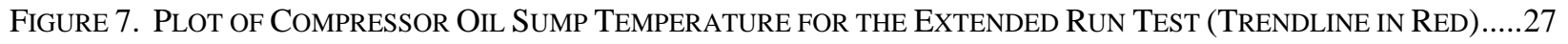




\section{Abbreviations}

\begin{tabular}{|c|c|}
\hline Btu & British thermal unit \\
\hline${ }^{\circ} \mathrm{C}$ & degrees Celsius \\
\hline $\mathrm{CFC}$ & chlorofluorocarbon \\
\hline CJC & cold junction compensation \\
\hline $\mathrm{COP}$ & coefficient of performance \\
\hline $\mathrm{cSt}$ & centistokes \\
\hline DAQ & data acquisition system \\
\hline DOE & Department of Energy \\
\hline EIA & Energy Information Administration \\
\hline FID & flame ionization detector \\
\hline $\mathrm{HCFC}$ & hydrochlorofluorocarbon \\
\hline $\mathrm{HFC}$ & hydrofluorocarbon \\
\hline $\mathrm{J}$ & Joule \\
\hline $\mathrm{K}$ & degrees Kelvin \\
\hline $\mathrm{kPa}$ & kiloPascals \\
\hline $\mathrm{kW}$ & kilowatt \\
\hline $\mathrm{kWh}$ & kilowatt-hour \\
\hline POE & polyol ester \\
\hline PTxy & pressure-temperature-composition \\
\hline psi & pounds per square inch \\
\hline psia & pounds per square inch absolute \\
\hline psig & $\begin{array}{l}\text { pounds per square inch gauge (i.e., above atmospheric } \\
\text { pressure) }\end{array}$ \\
\hline $\mathrm{R}$ & refrigerant \\
\hline SBIR & small business innovation research \\
\hline SEER & $\begin{array}{l}\text { Seasonal Energy Efficiency Rating, a measure of the } \\
\text { overall energy efficiency of an air conditioner through a } \\
\text { typical climate season }\end{array}$ \\
\hline SPOSS & Single Phase Optimizing Soft Starters \\
\hline U.S. & United States \\
\hline
\end{tabular}


High Energy Efficiency Air Conditioning

\section{Executive Summary}

This project determined the performance of a new high efficiency refrigerant, Ikon ${ }^{\circledR} \mathrm{B}$, in a residential air conditioner designed to use $\mathrm{R}-22$.

The refrigerant R-22, used in all residential and small commercial air conditioners, is being phased out of production in developed countries beginning this year because of concerns regarding its ozone depletion potential. Although a replacement refrigerant, $\mathrm{R}-410 \mathrm{~A}$, is available, it operates at much higher pressure than R-22 and requires new equipment. R-22 air conditioners will continue to be in use for many years to come. Air conditioning is a large part of expensive summer peak power use in many parts of the U.S. Previous testing and computer simulations of Ikon ${ }^{\circledR} \mathrm{B}$ indicated that it would have $20-25 \%$ higher coefficient of performance (COP, the amount of cooling obtained per energy used) than R-22 in an air-cooled air conditioner.

In this project, a typical new R-22 residential air conditioner was obtained, installed in a large environmental chamber, instrumented, and run both with its original charge of R-22 and then with $\mathrm{Ikon}^{\circledR} \mathrm{B}$. In the environmental chamber, controlled temperature and humidity could be maintained to obtain repeatable and comparable energy use results. Tests with $\mathrm{Ikon}^{\circledR} \mathrm{B}$ included runs with and without a power controller, and an extended run for several months with subsequent analyses to check compatibility of $\mathrm{Ikon}^{\circledR} \mathrm{B}$ with the air conditioner materials and lubricant.

Baseline energy use of the air conditioner with its original R-22 charge was measured at $90^{\circ} \mathrm{F}$ and $100^{\circ} \mathrm{F}$. After changeover to Ikon ${ }^{\circledR} \mathrm{B}$ and a larger expansion orifice, energy use was measured at $90^{\circ} \mathrm{F}$ and $100^{\circ} \mathrm{F}$. Ikon ${ }^{\circledR} \mathrm{B}$ proved to have about $19 \%$ higher $\mathrm{COP}$ at $90^{\circ} \mathrm{F}$ and about $26 \%$ higher $\mathrm{COP}$ at $100^{\circ} \mathrm{F}$ versus R-22. Ikon ${ }^{\circledR} \mathrm{B}$ had about $20 \%$ lower cooling capacity at $90^{\circ} \mathrm{F}$ and about $17 \%$ lower cooling capacity at $100^{\circ} \mathrm{F}$ versus $\mathrm{R}-22$ in this system. All results over multiple runs were within $1 \%$ relative standard deviation (RSD). All of these values agree well with previous results and computer simulations of Ikon ${ }^{\circledR} \mathrm{B}$ performance versus R-22. The lower cooling capacity of Ikon ${ }^{\circledR} \mathrm{B}$ is not a concern unless a particular air conditioner is near its maximum cooling capacity in application. Typically, oversized $\mathrm{A} / \mathrm{C}$ systems are installed by contractors to cover contingencies. In the extended run with Ikon ${ }^{\circledR} \mathrm{B}$, which covered the period from May $19^{\text {th }}$ to October $1^{\text {st }}$ at $100^{\circ} \mathrm{F}$ ambient temperature and $68 \%$ compressor on time, the air conditioner performed well with no significant loss of energy efficiency. Post-run analysis of the refrigerant, compressor lubricant oil, compressor, compressor outlet tubing, and the filter/dryer showed minor effects but nothing that was considered significant.

The project was very successful. All objectives were achieved, and the performance of Ikon ${ }^{\circledR} \mathrm{B}$ indicates that it can easily be retrofitted into R-22 air conditioners to give $15-20 \%$ energy savings and a $1-3$ year payback of retrofit costs depending on location and use. Ikon ${ }^{\circledR} \mathrm{B}$ has the potential to be a successful commercial product. 
High Energy Efficiency Air Conditioning

\section{Introduction}

\section{Background}

\section{The Opportunity}

Air conditioning is a major consumer of electric power in the U.S. In particular, air conditioning uses a considerable amount of expensive peak electric power, causing higher costs and inefficiency in power generation and distribution. The DOE's Energy Information Administration (EIA) collects data on air conditioning energy use in the U.S. In data from 1997, the EIA gives a value of 122 billion kWh energy use for electric air conditioning over the 72.6 million U.S. households that have electric air conditioning. In addition, according to the EIA the average SEER of installed central air conditioners was 10.66 in 1997. The average air conditioner in 1997 used about $1680 \mathrm{kWh} / \mathrm{yr}$, or, using the conversion value of $10,500 \mathrm{Btu} / \mathrm{kWh}$ supplied by DOE, about 17.6 million Btu/yr/unit. Much of this is used during peak summer electric use periods. It would be desirable to reduce this energy use and cost.

Essentially all U.S. residential and small commercial air conditioners use R22 refrigerant. This refrigerant, a hydrochlorofluorocarbon (HCFC), has been used for many years because it is readily available commercially, has good cooling capacity, and has reasonable energy efficiency. However, because of concern about its ozone depletion potential, R-22 is being phased out of production in developed countries beginning with a $35 \%$ reduction in R-22 production in 2003 , followed by a $65 \%$ reduction in 2006 , and complete elimination of production in 2010 . The current front-running replacement for R-22 is R-410A, a near-azeotropic blend of hydrofluorocarbons (HFCs) 125 and 32. This new refrigerant is inherently not quite as energy efficient as R-22, but this can be compensated for by improved equipment design. However, R-410A operates at considerably higher pressures than R-22 and requires completely new equipment. Estimates are that replacing existing R-22 A/C units over the next ten to fifteen years will cost U.S. consumers (including the federal government) about $\$ 30$ billion. It would be desirable if the life of existing $\mathrm{A} / \mathrm{C}$ equipment could be extended along with achieving improved energy efficiency.

\section{The Innovation}

In 1992, Dr. Jon Nimitz and Mr. Lance Lankford began work on a new family of replacements for ozone-depleting compounds such as CFCs, halons, and HCFCs. These replacements are blends containing fluoroiodocarbon compounds.

Fluoroiodocarbons, while thermally stable, break down quickly when exposed to the ultraviolet light in sunlight. Thus, they never reach the stratosphere and do not deplete the stratospheric ozone layer. At the same time, fluoroiodocarbons are excellent flammability suppressants and have attractive physical properties for use in refrigerants, solvents, firefighting agents, foam blowing agents, sterilants, nonflammable propellants, and other applications. Dr. Nimitz and Mr. Lankford filed a U.S. patent covering the fluoroiodocarbon blends, which was later split into 
several use and composition applications by the U.S. Patent Office. A number of foreign patent applications were also filed.

In 1997, Dr. Nimitz was awarded a Small Business Innovation Research (SBIR) Phase I contract from NASA Kennedy Space Center (KSC) to develop atmospherically friendly, high cooling capacity, energy efficient refrigerants for replacement of ozone-depleting refrigerants such as R-12 and R-22 in NASA equipment. In this Phase I effort, Dr. Nimitz developed Ikon ${ }^{\circledR} \mathrm{B}$, a nonflammable, azeotropic blend of $\mathrm{CF}_{3} \mathrm{I}, \mathrm{HFC}-134 \mathrm{a}$, and HFC-152a. Ikon ${ }^{\circledR} \mathrm{B}$ proved to be an excellent retrofitable replacement for both R-12 and R-134a. In ETEC's in-house tests, Ikon ${ }^{\circledR} \mathrm{B}$ appeared to have significantly greater cooling capacity and higher energy efficiency than R-12 or R-134a. ETEC arranged with Oak Ridge National Laboratories to test Ikon ${ }^{\circledR}$ B versus R-22 in their Vapor Compression Test Loop. The results showed than $\mathrm{Ikon}^{\circledR} \mathrm{B}$ had a $20-25 \%$ higher coefficient of performance (COP) than R-22, although considerably less volumetric cooling capacity. COP is a measure of the amount of cooling obtained per amount of energy used in a refrigeration system. Thus, in a well designed system a refrigerant with $20 \%$ higher COP should provide the same amount of cooling for $20 \%$ less energy. In the subsequent Phase II SBIR effort for NASA KSC, Ikon ${ }^{\circledR}$ B was demonstrated as a replacement for R-12 in a 20 ton ( a "ton" in this context is $12,000 \mathrm{Btu} / \mathrm{hr}$ of cooling) portable cooling unit used for providing pre-launch cooling to the Space Shuttle crew cabin.

In a Phase I and II SBIR project for the U.S. EPA, several fluoroiodocarbon blend refrigerant candidates including $\mathrm{Ikon}^{\circledR} \mathrm{B}$ were tested in residential refrigerators. Ikon ${ }^{\circledR} \mathrm{B}$ proved to be the most energy efficient and cost-effective. Because Ikon ${ }^{\circledR} \mathrm{B}$ has considerably more volumetric cooling capacity than R-134a, the compressor size in a refrigerator can be reduced to obtain energy savings. Underwriters Laboratories, Inc. (UL) tested ETEC's final version of a standard residential refrigerator using Ikon ${ }^{\circledR} \mathrm{B}$ refrigerant and a smaller compressor. UL's results were $11.6 \%$ lower overall energy use and $8.8 \%$ faster pulldown versus the baseline values with R-134a and the standard compressor. Because the smaller compressor used with Ikon ${ }^{\circledR} \mathrm{B}$ had about $15 \%$ less volumetric displacement than the standard compressor, but the refrigerator still had $8.8 \%$ faster pulldown, the estimated volumetric cooling capacity of Ikon ${ }^{\circledR} \mathrm{B}$ for this type of refrigerated cooling is more than $20 \%$ higher than that of R-134a. We believe that even greater overall energy use savings could have been obtained if a compressor more closely matched to Ikon ${ }^{\circledR}$ B's cooling capacity had been available. The effort was limited to standard sizes of commercially available R-134a refrigeration compressors. Compatibility and stability of Ikon ${ }^{\circledR} \mathrm{B}$ in these residential refrigerators were good. In extended run tests, refrigerators using Ikon ${ }^{\circledR}$ B logged a total of over 19,000 hours of compressor run time with no operational problems, or refrigerant or compressor oil decomposition. The compressors were broken down and inspected after extended running, and showed no signs of unusual wear or corrosion. 
A summary of performance results obtained with Ikon ${ }^{\circledR}$ B versus R-12 and R$134 \mathrm{a}$ in different types of refrigerated cooling equipment is given in Table 1.

Table 1. Compilation of Performance Test Results for Ikon ${ }^{\circledR}$ B

\begin{tabular}{|c|l|c|c|}
\hline $\begin{array}{c}\text { Versus } \\
\text { R- }\end{array}$ & Type of Equipment & $\begin{array}{c}\text { Relative Volumetric } \\
\text { Cooling Capacity }\end{array}$ & $\begin{array}{c}\text { Relative } \\
\text { COP }\end{array}$ \\
\hline $134 \mathrm{a}$ & Residential refrigerator & $>1.2$ & $>1.1$ \\
\hline 12 & Air-cooled water chiller & 1.13 & 1.11 \\
\hline $134 \mathrm{a}$ & Air-cooled water chiller & 1.09 & $1.13^{*}$ \\
\hline 12 & Air-cooled air conditioner** & 1.15 & 1.09 \\
\hline
\end{tabular}

* At least. Relative COP as high as 1.26 was seen during high ambient temperature operation.

** This unit was not a typical air conditioner, but a specialized 20 ton dieselpowered unit used by NASA for prelaunch cooling of the Space Shuttle cabin.

Computer simulations using Refprop ${ }^{\mathrm{TM}}$, NIST's refrigerant properties program, indicated that Ikon ${ }^{\circledR} \mathrm{B}$ has much higher COP than current air conditioning refrigerants, as shown in Table 2.

Table 2. Refprop ${ }^{\circledR} /$ COOLS Simulation Comparison of R-22 Replacements versus R-22 in Air-cooled Air Conditioning application $\left(40^{\circ} \mathrm{F}\right.$ evaporator, $130^{\circ} \mathrm{F}$ condenser)

\begin{tabular}{|l|c|c|c|c|c|c|}
\hline & $\begin{array}{c}\text { Relative } \\
\text { Volumetric } \\
\text { Cooling } \\
\text { Capacity }\end{array}$ & $\begin{array}{c}\text { Relative } \\
\text { Coefficient of } \\
\text { Performance }\end{array}$ & $\begin{array}{c}\text { Low Side } \\
\text { Operating } \\
\text { Pressure } \\
\text { (psia) }\end{array}$ & $\begin{array}{c}\text { High Side } \\
\text { Operating } \\
\text { Pressure } \\
(\mathbf{p s i a})\end{array}$ & $\begin{array}{c}\text { Compressor } \\
\text { Outlet } \\
\text { Temperature } \\
\left({ }^{\circ} \mathbf{F}\right)\end{array}$ & $\begin{array}{c}\text { Temperature } \\
\text { Glide Across } \\
\text { Evaporator } \\
\left({ }^{\circ} \mathbf{F}\right)\end{array}$ \\
\hline R-22 & 1.00 & 1.00 & 83 & 312 & 259 & 0.0 \\
\hline R-407C & 1.01 & 0.94 & 85 & 355 & 244 & 9.1 \\
\hline R-404A & 1.06 & 0.94 & 101 & 371 & 221 & 0.6 \\
\hline R-410A & 1.41 & 0.91 & 133 & 491 & 256 & 0.2 \\
\hline R-507 & 1.08 & 0.94 & 105 & 379 & 220 & 0.04 \\
\hline Isceon $^{\circledR} 59$ & 0.90 & 0.95 & 83 & 330 & 218 & 6.5 \\
\hline \hline Ikon $^{\circledR} \mathrm{B}$ & $0.80-0.85^{*}$ & $1.20-1.25^{* *}$ & 51 & 209 & 233 & 0.2 \\
\hline
\end{tabular}

*Based on known relative capacities of $R-22$ and $R-134 a$, and comparison of cooling capacities of $R$-134a and Ikon ${ }^{\circledR} B$ during EPA-sponsored refrigerator tests.

** Measured versus R-22 by Oak Ridge National Laboratories in their Vapor Compression Test Loop, and confirmed in testing versus R-134a and R-12 at ETEC.

Note also that Ikon ${ }^{\circledR} \mathrm{B}$ has much lower operating pressure and considerably lower predicted compressor outlet temperature versus R-22 and R-410A. The lower operating pressures and temperature should extend compressor and $\mathrm{A} / \mathrm{C}$ unit life considerably, particularly for units operating in very warm climates. 


\section{Project Goals}

The overall goal of this effort was to determine the performance of Ikon ${ }^{\circledR} \mathrm{B}$ in an air-cooled R-22 air conditioner.

The specific objectives of this effort were:

1. Install and instrument a standard residential air conditioner in ETEC's environmental chamber.

2. Measure the baseline energy use of the air conditioner with its original charge of $\mathrm{R}-22$ at $90^{\circ} \mathrm{F}$ and $100^{\circ} \mathrm{F}$ ambient temperatures.

3. Install Ikon ${ }^{\circledR} \mathrm{B}$ in the air conditioner and measure its energy use at $90^{\circ} \mathrm{F}$ and $100^{\circ} \mathrm{F}$ ambient temperatures, with and without a power controller on the compressor.

4. Perform an extended run with $\mathrm{Ikon}^{\circledR} \mathrm{B}$ in the air conditioner with subsequent analysis to check compatibility.

There was no variance from the original project goals.

\section{Results}

\section{Task 1. Obtain and Install Air Conditioner}

\section{Background Information}

To establish the performance of Ikon ${ }^{\circledR} \mathrm{B}$ versus $\mathrm{R}-22$ in a residential air conditioner, we had to obtain a new $\mathrm{R}-22$ residential air conditioner and install it in an area where temperature and humidity could be well controlled to obtain accurate and reproducible energy use test results. ETEC has a walk-in environmental chamber that was quite adequate for this purpose. A new residential air conditioner was used to eliminate any effects from prior wear.

\section{Environmental Chamber}

All energy tests and the extended run test were conducted in a walk-in environmental chamber.

The environmental chamber is a modified refrigerated transport unit acquired from the Dole Food Company. It is well insulated and can maintain below freezing temperatures if necessary. During colder months, the interior air of the refrigerated transport is heated with four baseboard heaters (6000W total) and controlled via a PID controller. Trim cooling is provided with the existing transport unit's refrigeration system and controlled via the same PID controller. This modified refrigerated transport is capable of accurately maintaining $15-60 \%$ relative humidity and $55^{\circ} \mathrm{F}$ to $125^{\circ} \mathrm{F}$ despite seasonal temperature fluctuations. The 
environmental chamber is compartmentalized, which allowed us to separate the air conditioner condensing unit and the evaporator/air handling unit, much as they would be separated in a typical split system residential air conditioner installation. Power outlets, shelves, and required control systems have been installed in the environmental chamber making it versatile for testing which requires continuous temperature and humidity control. Figure 1 shows a representation of the test setup.

Since the energy use of any air conditioning system is particularly sensitive to ambient temperature, the control (input temperature) variable for the PID controller was the average temperature reading of a gang of four T-type thermocouples surrounding the air intake of the condensing unit. This method of controlling the environmental chamber temperature minimized temperature fluctuations among runs and provided energy data with excellent reproducibility.

\section{Split System Air Conditioner}

The purpose of this task was to procure and install the necessary equipment to test and demonstrate Ikon ${ }^{\circledR} \mathrm{B}$ in a standard split system central air conditioner. A modern 2 ton, split system, R-22 residential air conditioner was purchased and installed in the environmental chamber. In addition, appropriate electrical wiring and disconnect boxes were installed to supply electricity to the condenser unit. The refrigerant lines between the condenser unit and evaporator unit were at least 25 feet long to simulate line lengths typically found in a split system installation. The condenser air inlet was taken from the environmental chamber ambient air. Tables 3 and 4 give the specifications for the air conditioner evaporator and condenser units.

An appropriately sized air handling unit with integral evaporator coils and air filter was used to provide cooled air circulation. The evaporator air inlet and outlet were connected by a loop of un-insulated duct to an air mixing box (see Figure 2 for details) to simulate the indoor air temperature and humidity conditions of a house or apartment. The air mixing box was operated by an air pressurized damper motor. The damper motor was in turn controlled by a PID controller, which maintained the air temperature in the return air duct. The return air temperature was set to $75^{\circ} \mathrm{F}$ for all tests.

Finally, the air conditioning system was initially charged with R-22 and leak checked as delivered from the air conditioning contractor. 


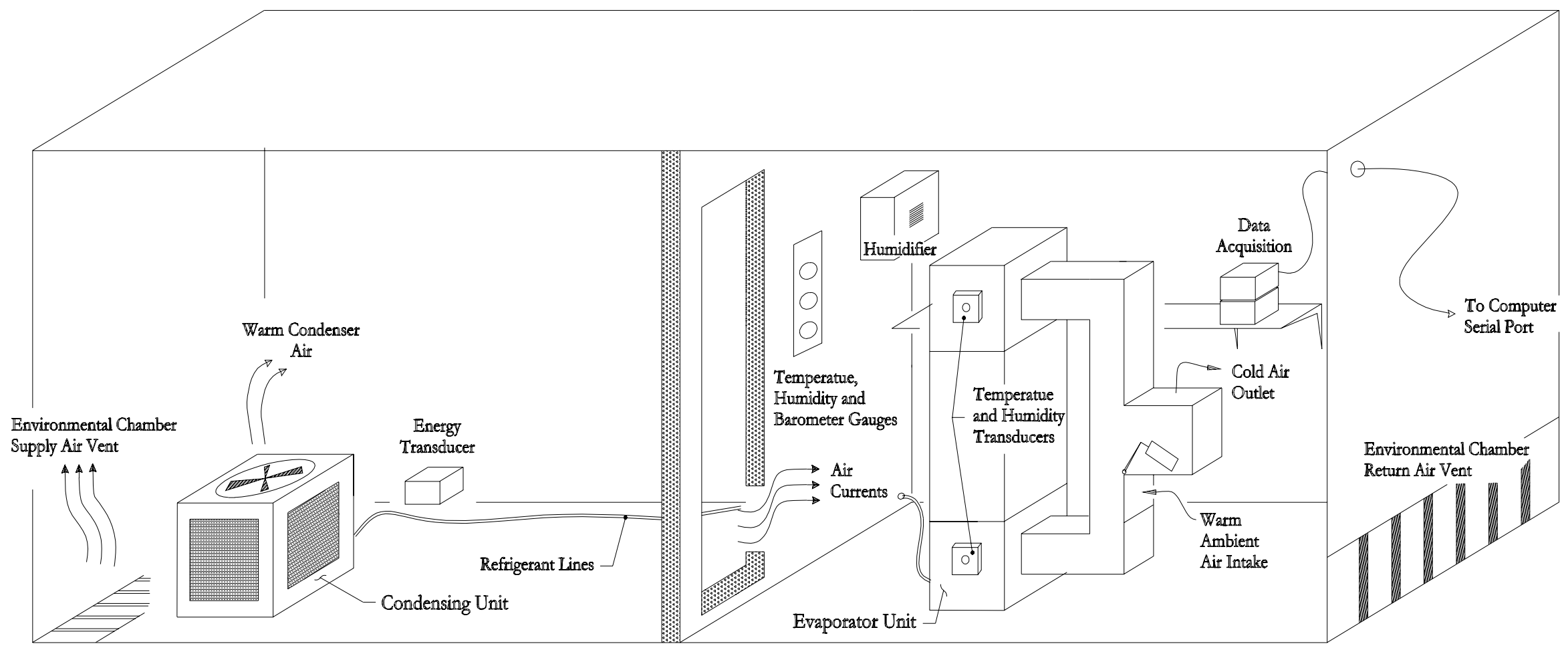

Figure 1. Environmental Chamber and Experimental Setup 
Table 3. Condensing Unit Technical Data

\begin{tabular}{|ll|}
\hline Condensing Unit Specifications & Bryant \\
Condensing Unit Manufacturer & $563 \mathrm{CN}$ 024-B \\
Condensing Unit Model Number & $2102 \mathrm{E} 19893$ \\
Condensing Unit Serial Number & 1.933 tons or $23200 \mathrm{BTU} / \mathrm{hr}$ \\
Factory Rated Capacity as Configured & $12.00 \mathrm{SEER}$ \\
Factory Rated Efficiency as Configured & $1 \phi 230 \mathrm{VAC} 60 \mathrm{~Hz}$ \\
Power Requirements & \\
& \\
Condenser Fan & $1 / 15 \mathrm{HP}(820 \mathrm{RPM})$ \\
Condenser Fan HP (RPM) & $1800 \mathrm{CFM}$ \\
Condenser Fan Airflow & \\
& \\
Refrigerant Specifications & $13{ }^{\circ} \mathrm{F}$ \\
Required Subcooling & $\mathrm{R} 22(5.25 \mathrm{lbs})$ \\
Refrigerant (amount) & \\
& \\
Compressor & Copeland \\
Compressor Manufacturer & $\mathrm{Scroll}$ \\
Compressor Type & $\mathrm{ZR} 22 \mathrm{~K} 3-\mathrm{PFV}-230$ \\
Model Number & $02 \mathrm{D} 5862 \mathrm{KL}$ \\
Serial Number & Sontex $200 \mathrm{LT}$ Mineral Oil \\
Oil Designation and Type & $1.12 \mathrm{~L}$ \\
Oil Charge & $6.43 \mathrm{~m}^{3} / \mathrm{hr}$ \\
Compressor Gas Flow Rate & $3500 \mathrm{RPM}$ \\
Motor RPM & \\
& $12.4 \mathrm{ft}^{2}$ \\
Condensing Coil & $25-1-2$ \\
Condensing Coil Face Area & \\
Fins Per Inch - Rows - Circuits & \\
\hline
\end{tabular}


Table 4. Evaporator / Air Handling Unit Technical Data

\begin{tabular}{|ll|}
\hline Air Handling I Evaporator Unit & \\
Specifications & \\
Evaporator Unit Manufacturer & Bryant \\
Evaporator Unit Model Number & FB4ANF024 \\
Evaporator Unit Serial Number & $1101 \mathrm{~A} 75483$ \\
Air Handler Type & Non-Heating Updraft \\
Power Requirements & $1 \phi 230 \mathrm{VAC} 60 \mathrm{~Hz}$ \\
& \\
Air Handler Fan & $1 / 4 \mathrm{HP}$ \\
Air Handler Fan HP & $850 \mathrm{CFM}$ \\
Air Handler Airflow (nominal) & \\
& \\
Evaporator Coil & $2.23 \mathrm{ft}^{2}$ \\
Evaporator Coil Face Area & Slope \\
Evaporator Coil Configuration & 3 and 14.5 \\
Rows and Fins Per Inch & \\
& \\
Refrigerant Metering Device & Orifice Piston \\
Refrigerant Metering Device Type & 061 \\
Refrigerant Metering Device size & \\
\hline
\end{tabular}


High Energy Efficiency Air Conditioning

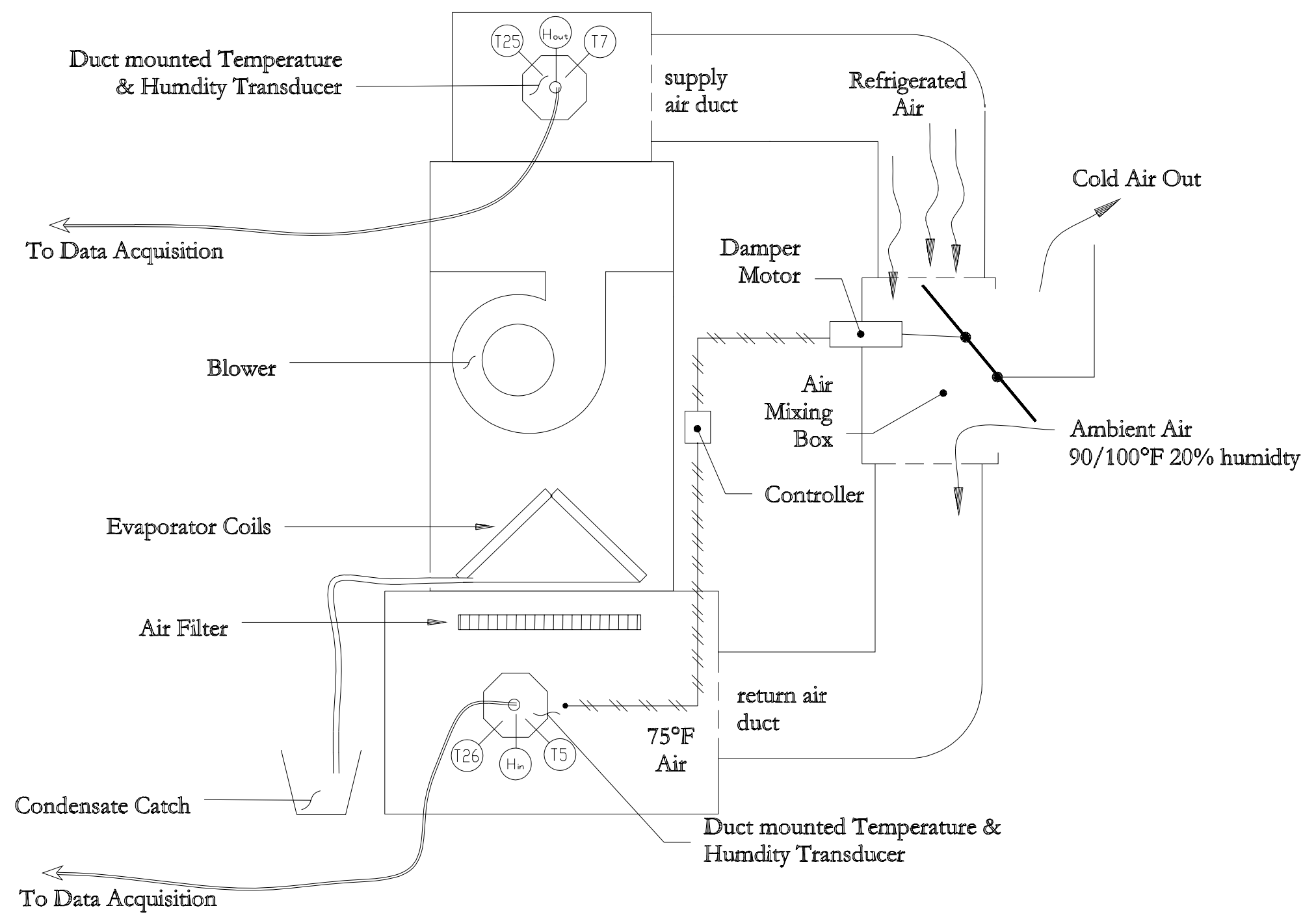

Figure 2. Evaporator / Air Handling Unit Schematic 
High Energy Efficiency Air Conditioning

\section{Instrumentation and Data Acquisition}

The data acquisition unit used was an OM-1050 with two thermocouple panels and one isolated signal conditioner on which two RTD modules were installed. Each thermocouple panel was capable of reading 16 thermocouples and the OM-1050 itself reads -10 to +10 VDC over each of its 8 analog channels. The isolated signal conditioner was capable of controlling 16 channels of input or output via 115 different user selectable modules. All data acquisition components were manufactured by Omega Engineering. Data logging and recording were accomplished by an Intel 686 class desktop computer running Labtech Notebook Pro software. Bi-directional communication was established via a serial RS-232 cable between the computer and the OM-1050.

All data recording and logging was automated and very little user intervention was required. Temperature, pressure, humidity, and energy data were recorded at one-minute intervals and written to a log file for later analysis.

\section{Thermocouple Locations}

Before testing began, a thermocouple calibration was performed to verify the accuracy of the temperature readings provided by the thermocouples and data acquisition unit. A typical T-type thermocouple with about $20 \mathrm{ft}$ of lead wire was fabricated, tested at two temperature calibration points, and the results compared to the temperature reading of a mercury-filled thermometer. The low temperature calibration point showed about $0.3^{\circ} \mathrm{C}$ of error and the high temperature calibration point showed about $0.7^{\circ} \mathrm{C}$ of error. This was within the expected error of this data acquisition system when used with T-type thermocouples.

Most thermocouple junctions were affixed to copper refrigerant pipes by soldering and thus the condition of electrically grounding the thermocouple junctions was satisfied. Thermocouple junctions not soldered to a copper refrigerant pipe were electrically grounded using a copper lead wire grounded on a nearby refrigerant pipe or at the data acquisition unit. Thermocouples attached to refrigerant lines were covered with insulating foam tape wrap to minimize ambient thermal effects. This approach of attaching thermocouples appeared to provide accurate temperatures with minimal lag time and minimal signal drift. To improve air temperature reading accuracy, two or more thermocouples were used to measure the temperature of a volume of air as opposed to the temperature of a point location for a single thermocouple. The average of multiple thermocouples (or thermocouple gangs) readings was used to measure the temperature of the evaporator inlet and outlet ducts and the ambient air surrounding the condenser.

A total of 10 thermocouple signals were used to measure various temperatures in the split air conditioning system and one thermocouple signal was used as the feedback signal to the environmental chamber PID temperature controller. 
Five T-type thermocouples were used to measure temperatures in the refrigerant lines. These were positioned at the evaporator outlet, evaporator saturated region, liquid refrigerant line before the expansion device, compressor discharge, and compressor suction. One T-type thermocouple was used to measure the compressor shell temperature at the oil sump. A sharp rise in oil sump temperature would perhaps indicate some incompatibility between $\operatorname{Ikon}^{\circledR} \mathrm{B}$ and the compressor materials or the compressor oil, causing increased friction heating in the compressor. We were also interested in the operating temperature of the compressor for reasons of general wear, i.e., a higher operating temperature might cause more wear in the compressor. A schematic representation of these six thermocouples is presented in Figure 3.

Four thermocouples measured the ambient air temperature surrounding the condenser unit, the condenser exit air, the evaporator supply duct, and the evaporator return duct. Table 5 describes all the data collected for the energy use experiments and the extended run test.

Two individual thermocouples were located at each of the geometric centers of the four air intakes of the condensing unit. Eight T-type thermocouples were placed around the condensing unit. The average of four thermocouples (a thermocouple gang) was used to record the temperature of the ambient air surrounding the condensing unit. The remaining four were used for the input signal to the PID controlling the environmental chamber temperature. All thermocouples surrounding the condenser were soldered to a loop of bare, heavy gauge copper grounding wire. Figures 4 and 5 show the condensing unit thermocouple locations.

\section{Pressure Transducers}

An Omega Engineering 0-100 psig pressure transducer was used to measure low side pressures and a 0-200 psig unit was used to measure high side pressures. These transducers were wired to the data acquisition unit and corresponding voltage calibration equations were programmed into the DAQ unit.

A brass manifold gauge set was modified to accommodate the electronic pressure transducers. The gauge set was attached to the high pressure and low pressure ports of the refrigerant circuit and thoroughly leaked checked with soap solution and an electronic refrigerant "sniffer." The gauge set remained attached during all the energy use tests to record pressures during operation with R-22 or Ikon ${ }^{\circledR} \mathrm{B}$. The gauge set also allowed simplified and expedient refrigerant evacuation and charging during changeover to Ikon ${ }^{\circledR}$ B. An effort was made to minimize the number of flare and/or compression fittings since these are more susceptible to small leaks. Soldered joints were used wherever possible. 
High Energy Efficiency Air Conditioning

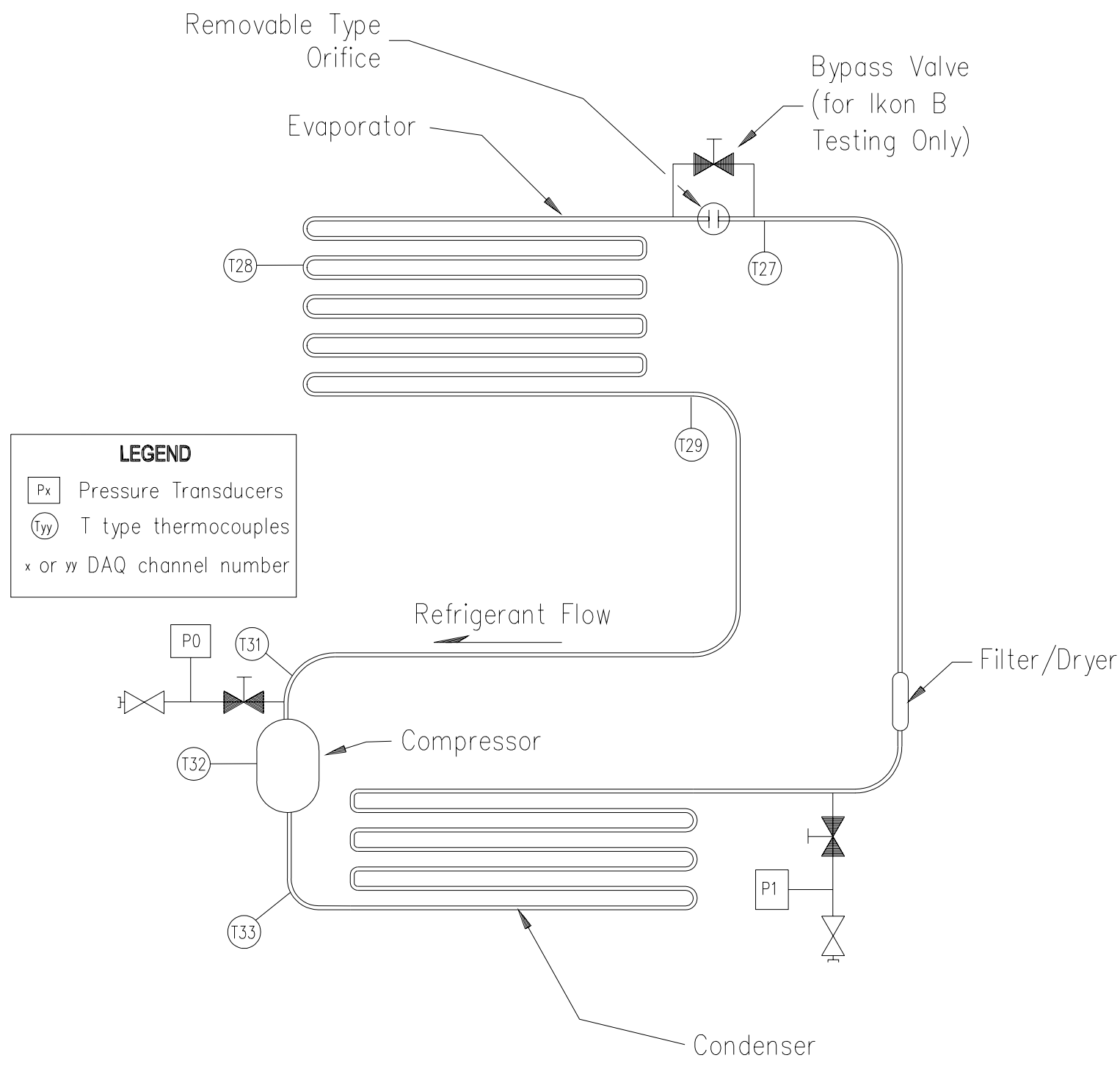

Figure 3. Schematic of Air Conditioning Refrigerant Circuit 
Table 5. Data Acquisition Channel Numbers and Descriptions

\begin{tabular}{|c|c|c|c|c|}
\hline $\begin{array}{l}\text { Channel } \\
\text { number in } \\
\text { record file }\end{array}$ & $\begin{array}{c}\text { Other } \\
\text { Designation }\end{array}$ & $\begin{array}{c}\text { Thermocouple } \\
\text { Type }\end{array}$ & Description & $\begin{array}{l}\text { Lead } \\
\text { Length }\end{array}$ \\
\hline 1 & $\mathrm{PO}$ & & Low Side Pressure (PSIG) & \\
\hline 2 & P1 & & High Side Pressure (PSIG) & \\
\hline 3 & & & Watts & \\
\hline 4 & & & Percent Relative Humidity (Ambient) & \\
\hline 5 & $\mathrm{H}_{\text {in }}$ & & Percent Relative Humidity (Return Duct) & \\
\hline 6 & T5 & RTD & Temperature (Return Duct) & \\
\hline 7 & $\mathrm{H}_{\text {out }}$ & & Percent Relative Humidity (Supply Duct) & \\
\hline 8 & T7 & RTD & Temperature (Supply Duct) & \\
\hline 9 & & & Watt-Hours & \\
\hline 10 & & & Time in seconds & \\
\hline 11 & & CJC & Cold Junction Compensation (CJC1) & \\
\hline 12 & & CJC & Cold Junction Compensation (CJC2) & \\
\hline 13 & T24 & $\mathrm{T}$ & $\begin{array}{l}\text { ambient air temperature around } \\
\text { condenser unit thermocouple gang } \\
\text { (average of } 4 \text { individual thermocouples) }\end{array}$ & $20 \mathrm{ft}$ \\
\hline 14 & T25 & $\mathrm{T}$ & $\begin{array}{l}\text { supply duct temperature thermocouple } \\
\text { gang (average of 2) }\end{array}$ & $18 \mathrm{ft}$ \\
\hline 15 & T26 & $\mathrm{T}$ & $\begin{array}{l}\text { return duct temperature thermocouple } \\
\text { gang (average of } 2 \text { ) }\end{array}$ & $18 \mathrm{ft}$ \\
\hline 16 & T27 & $\mathrm{T}$ & $\begin{array}{l}\text { liquid refrigerant line before expansion } \\
\text { device (6" from device) }\end{array}$ & $18 \mathrm{ft}$ \\
\hline 17 & T28 & $\mathrm{T}$ & Evaporator Saturated Region & $18 \mathrm{ft}$ \\
\hline 18 & T29 & $\mathrm{T}$ & Vapor line after evaporator & $18 \mathrm{ft}$ \\
\hline 19 & T30 & $\mathrm{T}$ & $\begin{array}{l}\text { air temperature above condenser unit } \mathrm{T} \\
\text { thermocouple }\end{array}$ & $20 \mathrm{ft}$ \\
\hline 20 & T31 & $\mathrm{T}$ & $\begin{array}{l}\text { compressor suction temperature (8" } \\
\text { from compressor body) }\end{array}$ & $20 \mathrm{ft}$ \\
\hline 21 & T32 & $\mathrm{T}$ & Compressor Shell at Oil Sump & $20 \mathrm{ft}$ \\
\hline 22 & T33 & $\mathrm{T}$ & $\begin{array}{l}\text { compressor outlet (6" from compressor } \\
\text { body) }\end{array}$ & $20 \mathrm{ft}$ \\
\hline
\end{tabular}




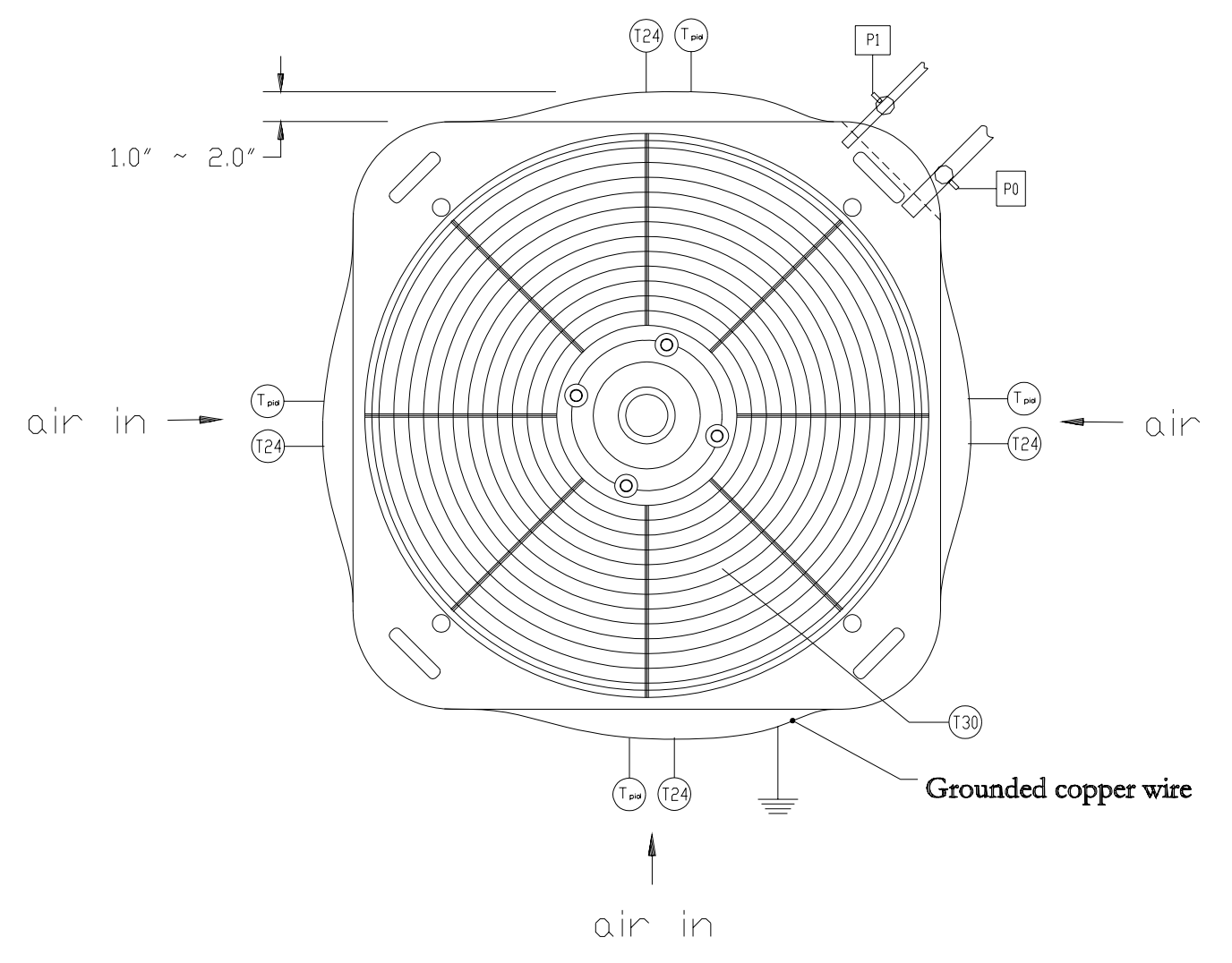

Figure 4. Top View of Condensing Unit with Thermocouples Locations

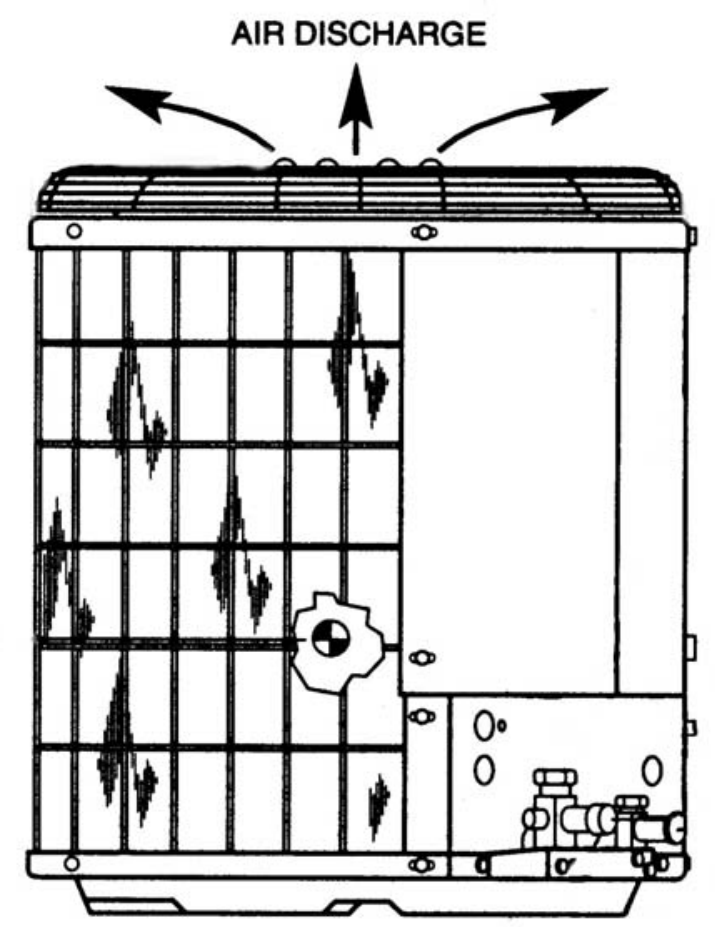

Figure 5. Side View of Condensing Unit (Scanned from Product Literature) 
High Energy Efficiency Air Conditioning

\section{Energy Transducer}

An Ohio Semitronics energy transducer was used to measure energy use of the condenser unit (compressor and condenser fan energy). This particular model can read 0-20 amps (4000 watts full-scale) with 0-300VAC $60 \mathrm{~Hz}$ single-phase electricity. Watt use is scaled to a signal range of 0-10 VDC for convenient hookup to a variety of logging instruments. The internal counter of the DAQ was used to count $+5 \mathrm{~V}$ TTL pulses (one pulse represents one watt-hour) and a stand-alone digital counter was used for backup verification of the internal DAQ counter. The accuracy for this energy transducer is rated at 0.2 percent of reading.

\section{Humidity Sensors}

Two duct-mounted humidity and temperature transmitters were constructed to measure the energy content of the air entering and exiting the evaporator unit. The OMEGA Model EWS-RH is a combination dual output, relative humidity/ temperature transmitter. A thin film temperature compensated, polymer capacitor senses relative humidity while a solid state RTD temperature sensor measures ambient temperature. Signals are scaled to 1-5 VDC output and connected to the DAQ via shielded cable.

The OMEGA Model EWS-RH sensors were installed offset from a duct mounting plate using wooden dowels, placing the sensors well into the air stream of the duct for accurate measurement of the flowing air's temperature and relative humidity.

\section{Task 2. Baseline air conditioner energy use}

\section{Test Description}

After the air conditioner was fully instrumented and the controls systems were verified to be in good working order, baseline energy use testing was begun.

Each trial run for baseline R-22 energy use took less than 8 hours. The air conditioner was allowed to "soak" at the ambient test temperature (either $90^{\circ} \mathrm{F}$ or $100^{\circ} \mathrm{F}$ ) overnight. The temperature setting for the PID controller for the return duct air temperature was verified to be $75^{\circ} \mathrm{F}$. Other control system settings were verified and the air conditioner was then turned on and allowed to run continuously without thermostatic control under maximum load for the test temperature conditions.

The air conditioner was allowed to reach steady state operation. This was typically achieved within 3-4 hours. Runs were typically 6-7 hours to ensure equilibrium conditions. The final hour of temperature and energy data were averaged and these values were used to calculate steady state energy performance for each run. At least three runs for each test set were then averaged and standard deviations were calculated to verify the repeatability of the data. Using a $100 \mathrm{~mL}$ graduated cylinder and timer, the rate of water condensation for the evaporator coil was recorded near the end of each run. 
The second part of baseline energy testing involved adding a power controller device or Nola device, sometimes referred to as a "power factor controller," (although this may be a misnomer) to the air conditioner compressor to attempt to compensate for loss of compressor motor efficiency under partial load. This device was originally developed and patented by Frank Nola at NASA in the mid-1970s as a way to increase the efficiency of small, single-phase AC induction motors by sensing the difference in phase angle between the voltage and amperage and lowering the average voltage to save power in unloaded or partially loaded motors. There have been a number of patented variations and attempted improvements on the original technology, but the basic idea is the same. Unfortunately, the field of energy efficiency devices has been subject to a large number of questionable and untrue claims for products, which has made many people very suspicious of power controller devices. One often-used deceptive tactic is to cite power use at the motor as a measure of power savings, when it is power use at the meter that measures power savings.

The manner in which power controller devices sold today modify the voltage wave is unclear and seems to be a secret guarded by the manufacturers. These devices are marketed under various trade names such as Power Planner ${ }^{\mathrm{TM}}$, Performance Controller ${ }^{\mathrm{TM}}$, or Power Wise ${ }^{\mathrm{TM}}$. One must be extremely careful about claims regarding these devices. For instance, Power Planner ${ }^{\mathrm{TM}}$ provided us with a brochure that gave supposed testimonials of energy savings from large clients. However, upon our contacting most of these clients, every one of them stated that the testimonial claimed by Power Planner ${ }^{\mathrm{TM}}$ was untrue and several indicated that they had initiated legal action against Power Planner ${ }^{\mathrm{TM}}$ regarding the testimonial attributed to them.

Initially, we selected the Performance Controller ${ }^{\mathrm{TM}}$ marketed by the Power Efficiency Corporation as the best candidate for our testing. The Performance Controller ${ }^{\mathrm{TM}}$ seemed to be legitimate and the company made what appeared to be realistic claims for energy savings. Unfortunately, this company was uncooperative when asked to provide us a unit for our testing, and this was felt to be a "red flag" for use of this device. Instead, we obtained from Fairford Electronics the SPOSS


conditioning system. The manufacturer claims that this unit has a proprietary method of optimization that is particularly effective for air conditioning systems using a hermetic compressor, as the following quotes from the product literature claim:

"An important new feature of the module is the addition of automatic Energy Optimizing based on the well-known Fairford System Patent."

"With optimizing selected, the controller will continuously adjust the motor terminal voltage so that the input energy corresponds to the mechanical output required. This reduces wasted power, improves efficiency and reduces motor heating. The effect is particularly beneficial in those applications which run at varying loads for extended periods of time such as refrigeration, air compressors etc. This method is quite 
different from other systems which insert a fixed delay in the power wave under all load conditions, and which sometimes leads to burned out motors."

The power controller device was installed in accordance with the manufacturer's instructions to control the compressor motor only and the AC supply to the condenser fan was left unmodified. For our testing, the power controller device was installed downline of the Ohio Semitronics energy metering unit so that we obtained a measure of the total arrangement's (i.e. compressor and power controller) power consumption. The Fairford power control unit was verified to be working, evidenced by a flashing status LED.

Testing and data analysis continued in the same manner as testing without the power controller. The complete test matrix for R-22 testing is show in Table 6 .

Table 6. R-22 Refrigerant Test Matrix

\begin{tabular}{|c|c|c|}
\hline $\begin{array}{c}\text { Condenser ambient } \\
\text { temperature, } \mathbf{o} \text { F }\end{array}$ & $\begin{array}{c}\text { Without power } \\
\text { controller }\end{array}$ & $\begin{array}{c}\text { With power } \\
\text { controller }\end{array}$ \\
\hline $\mathbf{9 0}$ & Average of 3 runs & Average of 3 runs \\
\hline 100 & Average of 4 runs & Average of 3 runs \\
\hline
\end{tabular}

\section{$\underline{\text { Data Analysis }}$}

The data acquired for each run was imported into Microsoft Excel ${ }^{\mathrm{TM}}$ for subsequent data analysis and formatting. Excel ${ }^{\mathrm{TM}}$ data filters were used with the $\log$ files to summarize pertinent data.

Psychrometric software was used with the collected data to do an energy balance analysis for the condensing unit and the air handler/evaporator unit. Cooling capacity and overall COP for the air conditioner were calculated using the temperature and humidity conditions of the air stream entering and exiting the evaporator unit in conjunction with the energy meter data. Table 7 shows a sample energy balance worksheet for the installed air conditioner with R-22 refrigerant at $90^{\circ} \mathrm{F}$ ambient condenser temperature. Standard deviations were typically less than 0.5 percent for temperature, pressure, and energy use, and about 3 percent for humidity data. 
Table 7. Sample Energy Balance Worksheet for Energy Use Tests

\begin{tabular}{|r|c|l|l|}
\hline \multicolumn{5}{|c|}{ conditions before evaporator } \\
\hline average return air temperature & ${ }^{\circ} \mathrm{C}$ & 24.1 & $0.01 \%$ \\
\hline average return air humidity & $\%$ & $38.2 \%$ & $1.39 \%$ \\
\hline local atmospheric pressure & $\mathrm{kPa}$ & 84.44 & \\
\hline & & & \\
\hline Wet-bulb temperature & ${ }^{\circ} \mathrm{C}$ & 14.6 & \\
\hline Dew-point temperature & ${ }^{\circ} \mathrm{C}$ & 9.0 & \\
\hline Humidity ratio & $\mathrm{kg} / \mathrm{kg}$ & 0.00858 & \\
\hline Enthalpy & $\mathrm{kJ} / \mathrm{kg}$ & 46.10 & \\
\hline Volume & $\mathrm{m}^{3} / \mathrm{kg}$ & 1.02 & \\
\hline
\end{tabular}

\begin{tabular}{|r|c|l|l|}
\hline \multicolumn{5}{|c|}{ conditions after evaporator } \\
\hline average supply air temperature & ${ }^{\circ} \mathrm{C}$ & 12.7 & $0.02 \%$ \\
\hline average supply air humidity & $\%$ & $78.6 \%$ & $0.82 \%$ \\
\hline local atmospheric pressure & $\mathrm{kPa}$ & 84.44 & \\
\hline & & & \\
\hline Wet-bulb temperature & ${ }^{\circ} \mathrm{C}$ & 10.6 & \\
\hline Dew-point temperature & ${ }^{\circ} \mathrm{C}$ & 9.2 & \\
\hline Humidity ratio & $\mathrm{kg} / \mathrm{kg}$ & 0.00865 & \\
\hline Enthalpy & $\mathrm{kJ} / \mathrm{kg}$ & 34.64 & \\
\hline Volume & $\mathrm{m}^{3} / \mathrm{kg}$ & 0.99 & \\
\hline
\end{tabular}

\begin{tabular}{|r|c|l|l|}
\hline \multicolumn{4}{|c|}{ ambient conditions in environmental chamber } \\
\hline ambient temperature & ${ }^{\circ} \mathrm{C}$ & 36.3 & $0.05 \%$ \\
\hline ambient humdity & $\%$ & $13.7 \%$ & $3.81 \%$ \\
\hline & & & \\
\hline local atmospheric pressure & $\mathrm{kPa}$ & 84.44 & \\
\hline Wet-bulb temperature & ${ }^{\circ} \mathrm{C}$ & 16.6 & \\
\hline Dew-point temperature & ${ }^{\circ} \mathrm{C}$ & 4.2 & \\
\hline Humidity ratio & $\mathrm{kg} / \mathrm{kg}$ & 0.00615 & \\
\hline Enthalpy & $\mathrm{kJ} / \mathrm{kg}$ & 52.32 & \\
\hline Volume & $\mathrm{m}^{3} / \mathrm{kg}$ & 1.06 & \\
\hline
\end{tabular}

\begin{tabular}{|r|c|l|l|}
\hline \multicolumn{5}{|c|}{ conditions before condenser } \\
\hline average temperature & ${ }^{\circ} \mathrm{C}$ & 33.7 & $0.01 \%$ \\
\hline Dew-point temperature & ${ }^{\circ} \mathrm{C}$ & 4.2 & \\
\hline local atmospheric pressure & $\mathrm{kPa}$ & 84.44 & \\
\hline & & & \\
\hline Wet-bulb temperature & ${ }^{\circ} \mathrm{C}$ & 15.8 & \\
\hline Relative humidity & ${ }^{\circ} \mathrm{C}$ & 0.2 & \\
\hline Humidity ratio & $\mathrm{kg} / \mathrm{kg}$ & 0.00616 & \\
\hline Enthalpy & $\mathrm{kJ} / \mathrm{kg}$ & 49.70 & \\
\hline Volume & $\mathrm{m}^{3} / \mathrm{kg}$ & 1.05 & \\
\hline
\end{tabular}

\begin{tabular}{|r|c|l|l|}
\hline \multicolumn{5}{|c|}{ conditions after condenser } & \\
\hline average temperature & ${ }^{\circ} \mathrm{C}$ & 43.0 & $0.01 \%$ \\
\hline Dew-point temperature & ${ }^{\circ} \mathrm{C}$ & 4.2 & \\
\hline local atmospheric pressure & $\mathrm{kPa}$ & 84.44 & \\
\hline & & & \\
\hline Wet-bulb temperature & ${ }^{\circ} \mathrm{C}$ & 18.6 & \\
\hline Relative humidity & ${ }^{\circ} \mathrm{C}$ & 0.1 & \\
\hline Humidity ratio & $\mathrm{kg} / \mathrm{kg}$ & 0.00616 & \\
\hline Enthalpy & $\mathrm{kJ} / \mathrm{kg}$ & 59.12 & \\
\hline Volume & $\mathrm{m}^{3} / \mathrm{kg}$ & 1.09 & \\
\hline
\end{tabular}

\begin{tabular}{|r|c|c|c|}
\hline \multicolumn{4}{|c|}{ Overall Performance } \\
\hline Delta Enthalpy Evaporator & $\begin{array}{c}\text { Watts } \\
\text { (BTU/hr) }\end{array}$ & 6040 & 20610 \\
\hline calculated condense rate for water & $\mathrm{kg} / \mathrm{hr}$ & -0.118 & \\
\hline actual condense rate for water & $\mathrm{mL} / \mathrm{hr}$ & 324 & $7.94 \%$ \\
\hline & & & \\
\hline Delta Enthalpy Condenser & $\begin{array}{c}\text { Watts } \\
(\mathrm{BTU} / \mathrm{hr})\end{array}$ & 7369 & 25145 \\
\hline Compressor Energy Usage & $\begin{array}{c}\text { Watts } \\
(\mathrm{BTU} / \mathrm{hr})\end{array}$ & 1728 & 5897 \\
\hline Fan + Compressor Energy Usage & $\begin{array}{c}\text { Watts } \\
(\mathrm{BTU} / \mathrm{hr})\end{array}$ & 1993 & 6801 \\
\hline without fan energy & COP & 3.495 & \\
\hline with fan energy & COP & 3.030 & \\
\hline
\end{tabular}


High Energy Efficiency Air Conditioning

\section{Task 3. Measure energy use with Ikon ${ }^{\circledR} \mathrm{B}$}

\section{$\underline{\text { Test Description }}$}

After R-22 baseline testing was completed, the R-22 refrigerant in the air conditioner was recovered and the refrigerant circuit was purged with dry nitrogen gas. A larger orifice valve (size 073, 20\% larger than stock size 061) was purchased and installed in place of the existing orifice valve in the refrigerant loop. Additionally, a needle valve was installed parallel to the orifice valve to allow precise adjustment of refrigerant flow into the evaporator for fine tuning the superheat of the refrigerant returning to the compressor (This fine tuning valve will not be needed with a correctly sized orifice.). After these mechanical changes were made, the refrigerant circuit was sealed and pressurized with $>100$ psig nitrogen gas and leak checked with soap solution. After the refrigerant circuit was verified to be leak free, the nitrogen gas was released and the circuit was evacuated for at least 4 hours to remove non-condensable gases, the remaining R-22 refrigerant, and any volatile liquids that might be present.

The recovered R-22 refrigerant was weighed and a corresponding amount of Ikon $^{\circledR} \mathrm{B}$ (about $5 \mathrm{lbs}$ ) was prepared based on the relative liquid densities of R-22 and Ikon ${ }^{\circledR} \mathrm{B}$ refrigerants. The Ikon ${ }^{\circledR} \mathrm{B}$ refrigerant was liquid charged into the high pressure side of the refrigerant circuit. The air conditioner was then energized and the remaining Ikon ${ }^{\circledR} \mathrm{B}$ was vapor charged into the low pressure side of the refrigerant circuit until only vapor remained in the charging cylinder.

The air conditioner was allowed to run for several hours to equilibrate and then the superheat of the Ikon ${ }^{\circledR} \mathrm{B}$ refrigerant was fine tuned using the orifice bypass needle valve. After fine-tuning, the freshly charged air conditioner was ready for energy use testing and data analysis in the same manner as with R-22 refrigerant. The following table shows the test matrix for Ikon ${ }^{\circledR} \mathrm{B}$ energy use measurements.

Table 8. Ikon $^{\circledR}$ B Refrigerant Test Matrix

\begin{tabular}{|c|c|c|}
\hline $\begin{array}{c}\text { Condenser ambient } \\
\text { temperature, } \mathbf{~} \mathbf{F}\end{array}$ & $\begin{array}{c}\text { Without power } \\
\text { controller }\end{array}$ & $\begin{array}{c}\text { With power } \\
\text { controller }\end{array}$ \\
\hline $\mathbf{9 0}$ & Average of 4 runs & Average of 4 runs \\
\hline 100 & Average of 3 runs & Average of 4 runs \\
\hline
\end{tabular}

\section{Operational Parameters and Energy Use Measurements}

The completed results for baseline R-22 and Ikon ${ }^{\circledR}$ B energy testing are presented in Table 9. These results include the total fan energy and compressor energy of the air conditioner. 
Table 9. Final Results for Energy Use of the Residential Split System Air Conditioner Charged with R-22 or Ikon ${ }^{\circledR}$ B

\begin{tabular}{|}
\hline \begin{tabular}{l}
$90^{\circ} \mathrm{F}$ ambient \\
\hline
\end{tabular} COP & $\begin{array}{c}\text { Evaporator } \Delta \mathrm{H} \\
(\mathrm{BTU} / \mathrm{hr})\end{array}$ & $\begin{array}{c}\text { Condenser } \Delta \mathrm{H} \\
(\mathrm{BTU} / \mathrm{hr})\end{array}$ & $\begin{array}{c}\text { Compressor }+ \\
\text { Fan } \Delta \mathrm{E}(\mathrm{BTU} / \mathrm{hr})\end{array}$ \\
\hline Ikon B with power controller & 3.50 & 16381 & 19467 & 4675 \\
\hline Ikon B without power controller & 3.49 & 16037 & 19320 & 4598 \\
\hline R-22 with power controller & 3.08 & & & \\
\hline R-22 without power controller & 3.03 & 20901 & 24940 & 6796 \\
\hline$\%$ change with power controller & $13.9 \%$ & $-21.6 \%$ & 25145 & 6801 \\
\hline$\%$ change without power controller & $15.1 \%$ & $-22.2 \%$ & $-21.9 \%$ & $-31.2 \%$ \\
\hline
\end{tabular}

\begin{tabular}{|}
\hline \begin{tabular}{l}
\hline $100^{\circ} \mathrm{F}$ ambient \\
\hline
\end{tabular} COP & $\begin{array}{c}\text { Evaporator } \Delta \mathrm{H} \\
(\mathrm{BTU} / \mathrm{hr})\end{array}$ & $\begin{array}{c}\text { Condenser } \Delta \mathrm{H} \\
(\mathrm{BTU} / \mathrm{hr})\end{array}$ & $\begin{array}{c}\text { Compressor }+ \\
\text { Fan } \Delta \mathrm{E}(\mathrm{BTU} / \mathrm{hr})\end{array}$ \\
\hline Ikon B with power controller & 3.13 & 16115 & 19262 & 5152 \\
\hline Ikon B without power controller & 3.22 & 16484 & 19339 & 5127 \\
\hline R-22 with power controller & 2.59 & 20205 & & 24470 & 7795 \\
\hline R-22 without power controller & 2.64 & 20561 & 25049 & 7784 \\
\hline$\%$ change with power controller & $20.7 \%$ & $-20.2 \%$ & $-21.3 \%$ & $-33.9 \%$ \\
\hline$\%$ change without power controller & $21.7 \%$ & $-19.8 \%$ & $-22.8 \%$ & $-34.1 \%$ \\
\hline
\end{tabular}

It can be seen from the data in Table 9 that no significant energy savings were observed using the power controller device tested.

Note that, without the power controller, at $90^{\circ} \mathrm{F}$ ambient temperature Ikon ${ }^{\circledR}$ B gives about $15 \%$ higher quantity of cooling obtained per amount of energy used, and at $100^{\circ} \mathrm{F}$ about $22 \%$ higher quantity of cooling obtained per amount of energy used, versus R-22. The cooling capacity (Evaporator $\Delta \mathrm{H}$ ) of the air conditioner decreases $20-22 \%$ with Ikon ${ }^{\circledR}$ B versus R-22, but this in many instances would be acceptable. In residential and small commercial air conditioning, this simply means that the air conditioner will run about $20 \%$ longer with $\mathrm{Ikon}^{\circledR} \mathrm{B}$ to provide the same amount of cooling it would have with R-22. The energy savings of Ikon ${ }^{\circledR} \mathrm{B}$ will be obtained even though the air conditioner runs longer, because COP is amount of cooling obtained per amount of energy used, independent of the run time.

The results obtained in Tasks 2 and 3 are highly precise and highly reproducible. They show large energy savings for Ikon ${ }^{\circledR} \mathrm{B}$ as a replacement for R-22 in air conditioners. In addition, the energy savings increases with increasing outside ambient temperature, giving the best savings when the most cooling is required. 
High Energy Efficiency Air Conditioning

\section{Task 4. Perform extended run test with Ikon $^{\circledR}$ B}

\section{$\underline{\text { Test Description and Setup }}$}

Ikon ${ }^{\circledR} \mathrm{B}$ was tested for materials compatibility with the air conditioner by performing an extended run test. Compressor performance was monitored throughout the extended run test with particular attention to any abnormal rise in compressor body temperature or energy use.

Since small leaks may cause slight compositional changes to Ikon ${ }^{\circledR} \mathrm{B}$ refrigerant and a GC analysis was planned for the recovered $\mathrm{Ikon}^{\circledR} \mathrm{B}$ following this test, a meticulous leak check of the air conditioner refrigerant circuit was performed. After energy use testing was completed, the Ikon ${ }^{\circledR} \mathrm{B}$ refrigerant in the refrigerant circuit was recovered and the circuit was purged with dry nitrogen gas. The system was sealed, pressurized with 140 psig nitrogen gas, leak checked with soap solution. After the refrigerant circuit was verified to be leak free, the nitrogen gas was released and the refrigerant circuit was evacuated for at least 4 hours to remove non-condensable gases, the remaining $\operatorname{Ikon}^{\circledR} \mathrm{B}$ refrigerant, and any volatile liquids that might be present.

About 5 lbs of fresh Ikon ${ }^{\circledR}$ B refrigerant was blended and then liquid charged into the high pressure side of the refrigerant circuit. The air conditioner was then energized and the remaining Ikon ${ }^{\circledR} \mathrm{B}$ was vapor charged into the low pressure side of the refrigerant circuit until only vapor remained in the charging cylinder.

The air conditioner was allowed to run for several hours to equilibrate, then the Ikon ${ }^{\circledR} \mathrm{B}$ superheat was verified to be within tolerance. No adjustment to the orifice bypass needle valve was needed.

The brass pressure gauge set with the pressure transducers was disconnected from the refrigerant circuit ports to minimize opportunities for leaks or permeation of Ikon ${ }^{\circledR}$ B out of the system. The access ports were securely capped and verified to be leak free with an electronic refrigerant leak detector.

Since the power controller device had provided no significant benefit in energy efficiency, it was removed.

\section{Extended Run Operational Parameters and Energy Use}

A timer was connected to the air conditioner to simulate thermostatic control. The duty cycle timer was programmed for 39 minutes of on time and 21 minutes of off time for a total cycle period of 60 minutes and $65 \%$ duty cycle. The actual duty cycle achieved in the extended run test is shown in Table 10. The data acquisition software was programmed to record data every 2.5 hours. This time interval captured data for some times when the compressor was off and some times when the compressor was on. 
The environmental chamber temperature controller was set to $100^{\circ} \mathrm{F}$ ambient temperature and the air conditioner was allowed to equilibrate at this temperature for about 2 days. Following the heat soak period, the return duct temperature was verified to be set at $75^{\circ} \mathrm{F}$ and the air conditioner was energized to start the extended run test.

Table 10 provides details for the extended run test.

Table 10. Parameters for Extended Run Test

\begin{tabular}{|l|l|}
\hline Condenser Ambient Temperature & $100^{\circ} \mathrm{F} \pm 2^{\circ} \mathrm{F}$ \\
\hline Evaporator Return Duct Temperature & $75^{\circ} \mathrm{F} \pm 3^{\circ} \mathrm{F}$ \\
\hline Evaporator Return Duct Humidity & $60 \% \pm 5 \%$ \\
\hline Actual duty cycle & $67.27 \%$ \\
\hline Run start time and date & $7: 30 \mathrm{am}$ May $19^{\text {th }}, 2003$ \\
\hline Run end time and date & $9: 11 \mathrm{am}$ October $1^{\text {st }}, 2003$ \\
\hline Recorded compressor on time & $2213.12 \mathrm{hrs}$ \\
\hline Total Watt-hour counts & 2926425 \\
\hline
\end{tabular}

\section{Post-Run Analysis}

After the extended run, the Ikon ${ }^{\circledR} \mathrm{B}$ refrigerant charge was recovered for later $\mathrm{GC}$ analysis and the refrigerant circuit was purged with dry nitrogen gas. The compressor's copper refrigerant inlet and outlet lines were severed and the compressor was removed from the condensing unit. About 1 pint of compressor oil was drained into a clean glass bottle. A gas port was soldered to the compressor's refrigerant suction line to allow evacuation and introduction of dry nitrogen gas to prevent air oxidation of the internal components of the compressor. The compressor was then purged with nitrogen gas and the lines sealed with high temperature brazing solder. The collected compressor oil and a baseline unused oil sample obtained from the compressor manufacturer were shipped to Spauschus Associates for analysis. The compressor was shipped to Dallas Hermetics for teardown and inspection.

Samples of the compressor discharge tubing and suction tubing were taken. The tubing ends were soldered shut and a gas port was added to evacuate and refill the tubing samples with dry nitrogen gas to prevent oxidation of the internal surface. A similar process was used to prepare the filter/dryer for analysis. The tubing and filter/dryer samples were shipped to New Hampshire Materials Lab for analysis.

Breakdown and inspection of the compressor showed no unusual attack or evidence of incompatibilities. There was one part, a plastic counterweight, which showed some unusual mechanical wear but that wear did not appear to be refrigerant-related. There was no evidence of any attack or softening of this part by 
the refrigerant. There was a small amount of dark, viscous, gel-like material in the sump and on the lower bearing but this did not seem to have had any affect on the operation of the compressor. Because the compressor oil is a mineral oil and R-134a (one of the components of Ikon B) is known to form a gel with mineral oil, there may be some amount of this occurring. By the small amount of gel seen, the extent of gelling is limited for Ikon ${ }^{\circ} \mathrm{B}$ with mineral oil.

The compressor oil analysis showed slightly elevated levels of acidity, iodine, and zinc, and very slightly elevated iron and silicon. Viscosity of the oil was essentially the same as unused oil ( $38 \mathrm{cSt}$ ), indicating no gross damage to or deterioration of the oil. The very slightly elevated iron and silicon are most likely from normal wear and are not a concern. Investigation of information on compressor lubricant oils has uncovered the fact that the presence of zinc can add up to 1 to 2 $\mathrm{mg} \mathrm{KOH/g}$ acidity to a lubricant oil, which is somewhat more than was seen in the acid number analysis of the post-test oil. It was also noted in the literature that the acidity of compressor lubricant oil is not considered a problem until it reaches about $20 \mathrm{mg} \mathrm{KOH} / \mathrm{g}$. The acidity increase in our post-test oil was well below $20 \mathrm{mg} \mathrm{KOH/g}$. There are, as far as we know, no parts containing zinc in the compressor or the remainder of the refrigerant circuit. We believe the zinc may have come from an anti-corrosion coating applied to the interior of the compressor. Note that Dallas Hermetics' report states that the sump and lower main bearing bracket oxidized (rusted) several hours after opening the compressor although the remainder of the steel parts did not. This indicates that a protective coating may have been removed from parts that were in the lubricant oil continuously. Zinc is routinely used as an anti-rust protective coating on iron and steel. In previous testing we have seen similar small amounts of both zinc and iodide in polyol ester (POE) compressor oil used with Ikon ${ }^{\circledR} \mathrm{B}$ in domestic refrigerators. The very small amounts of zinc and iodide do not appear to affect the operation of the refrigerators' cooling circuits, since we have now had these refrigerators running for over 4 years with no problems. As to why the zinc and iodine are in the lubricant oil, we speculate that it is because of formation of a Grignard-like trifluoromethylzinc iodide $\left(\mathrm{CF}_{3} \mathrm{ZnI}\right)$. Such compounds form fairly readily in non-aqueous solvents (Refs. 1 - 3) and compressor lubricating oil can be considered a non-aqueous solvent in this respect. It is likely that small equilibrium amounts of $\mathrm{CF}_{3} \mathrm{ZnI}$ formed in the compressor oil, which explains the similar amounts of both iodide and zinc found in the compressor oil. In the absence of water, $\mathrm{CF}_{3} \mathrm{ZnI}$ would remain stable and should not have any effect on the compressor or plumbing in such small concentrations.

The tubing samples and filter-dryer were analyzed by Scanning Electron Microscopy (SEM) and energy dispersive spectroscopy. The small diameter copper tubing was of the most interest because it was tubing on the compressor outlet and would have experienced the hottest and highest pressure conditions in the system. The inside surface of the small diameter copper tubing was in very good condition with no evidence of corrosion or deposits. The larger diameter copper tubing sample was from the compressor inlet, where pressure and temperature are low. This tubing had a very thin white surface scale containing significant carbon and iodine. 
Whatever the material is, it does not seem to have affected the operation of the air conditioner over time.

The filter/dryer was in as-fabricated condition. There was a small accumulation of solid debris that elemental analysis showed was mostly carbon, oxygen, aluminum, and silicon. There were smaller amounts of sodium, iron, and iodine. This debris appears to be just general debris from the cooling circuit, plus a small amount of the higher molecular weight iodocarbon. Again, it appears that this has had no effect on the operation of the air conditioner

Data collected for the extended run test was analyzed by identifying unusual trends such as an abrupt increase in compressor energy usage or a sharp rise in the compressor oil sump temperature, either of which may indicate imminent compressor failure. Most data recorded revealed no trend as shown by Figure 6 . Under these ambient conditions, the compressor energy usage averaged 1322 watts throughout the entire extended run.

In contrast to the compressor energy use, the compressor oil sump temperature (Figure 7) showed a very slight upward trend, with the red trendline increasing about $3^{\circ} \mathrm{C}$ to $4^{\circ} \mathrm{C}$ near the end of the extended run test. This result may be attributed to many factors. One possibility is that the compressor is experiencing some normal wear and will run somewhat hotter over time. The time we ran the air conditioner in this extended run test is the equivalent of two or three cooling seasons in most areas. Another possibility is that heat transfer surfaces are being somewhat fouled over time, reducing heat transfer and overall efficiency of the $\mathrm{A} / \mathrm{C}$ system. The temperature trend does not appear to be because of any incompatibility of the compressor or lubricant oil with Ikon ${ }^{\circledR}$ B. 




Figure 6. Plot of Compressor Energy Usage for the Extended Run Test (Trendline in Red) 


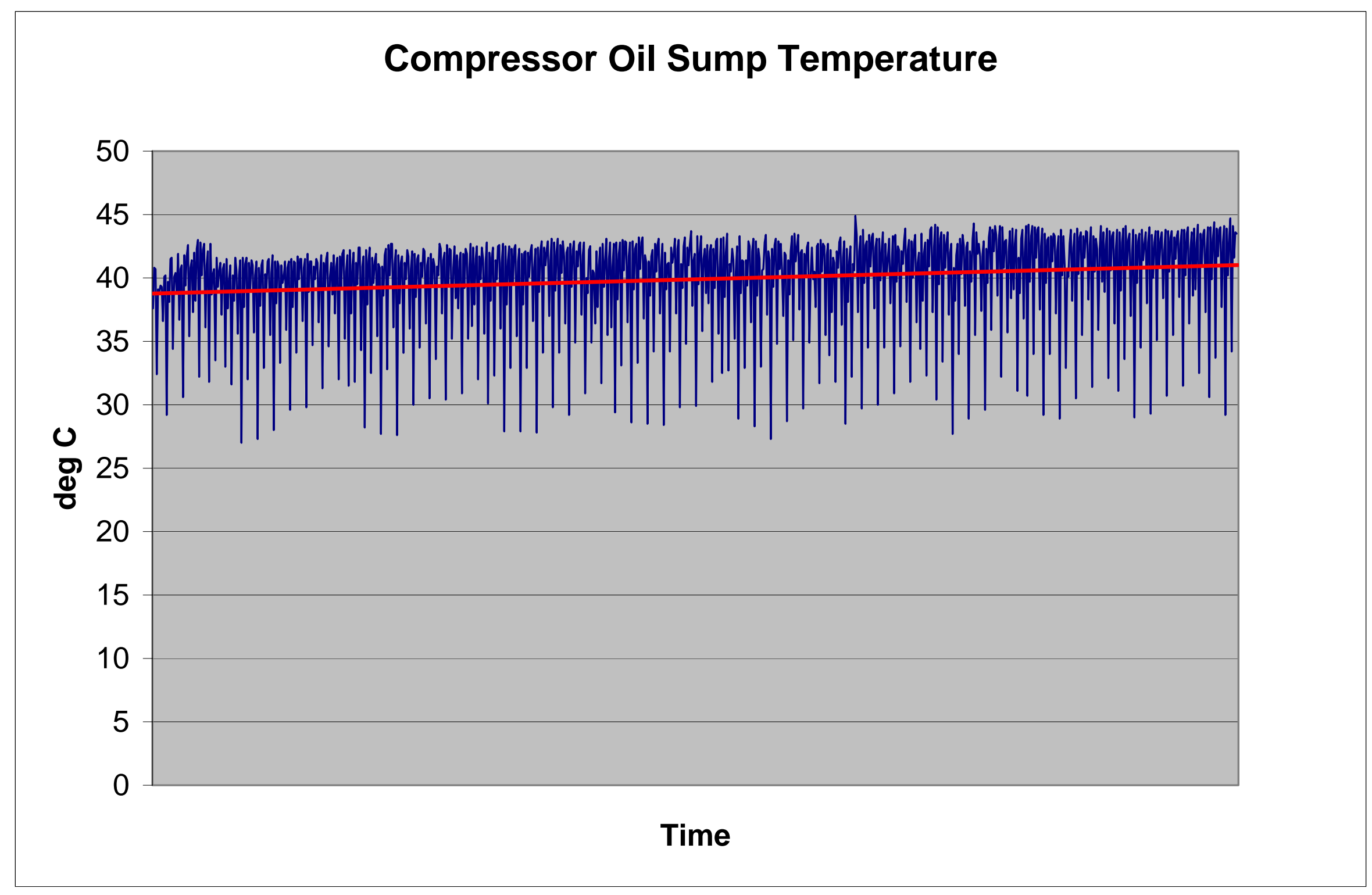

Figure 7. Plot of Compressor Oil Sump Temperature for the Extended Run Test (Trendline in Red) 


\section{Gas Chromatograph Analysis of Ikon ${ }^{\circledR}$ B after Extended Run}

GC analysis of Ikon B showed a small amount of compositional change after the extended run analysis. A new component observed is suspected to be $\mathrm{CF}_{3} \mathrm{H}$, a breakdown product of $\mathrm{CF}_{3} \mathrm{I}$. It was the most volatile component detected, and has been observed in other tests after prolonged heating of $\mathrm{CF}_{3} \mathrm{I}$ with oils at very high temperatures. The flame ionization detector (FID) response factor for $\mathrm{CF}_{3} \mathrm{H}$ was conservatively assumed to be the same as $\mathrm{CF}_{3} \mathrm{I}$, which has a relatively weak response. This assumption, taken with the peak area measured, would therefore overestimate the amount of $\mathrm{CF}_{3} \mathrm{H}$ present.

Taken with the traces of iodine found in the oil and on the compressor inlet tubing walls, this may indicate trace decomposition (between $0.02 \%$ and $0.1 \%$ ) of $\mathrm{CF}_{3} \mathrm{I}$ to $\mathrm{CHF}_{3}$ and iodide. This extended run involved prolonged and relatively harsh conditions, with a high compressor on-time ratio, simulating about three seasons of normal $\mathrm{A} / \mathrm{C}$ use. The fact that less than $0.1 \%$ decomposition of $\mathrm{CF}_{3} \mathrm{I}$ occurred during this run indicates that its stability is adequate for the operating lifetimes of $\mathrm{A} / \mathrm{C}$ equipment.

\section{Conclusions}

Ikon ${ }^{\circledR} \mathrm{B}$ appears to be suitable for direct replacement of R-22 in air conditioners, with a change of the expansion device to allow for the same refrigerant volume flow at the lower operating pressure.

Compared to R-22, Ikon ${ }^{\circledR} \mathrm{B}$ provides $15-20 \%$ more cooling per the same amount of energy used in a typical residential split system air conditioner (including the energy use of the air conditioner fans). Payback with Ikon ${ }^{\circledR} \mathrm{B}$ is estimated to be $1-3$ years depending on the location and local electricity price.

Ikon ${ }^{\circledR} \mathrm{B}$ appears to be compatible with all materials of construction of a typical R-22 air conditioner. It is also acceptably stable under $\mathrm{A} / \mathrm{C}$ application conditions.

Power controller devices do not appear to provide significant energy savings in air conditioners, either with R-22 or with Ikon ${ }^{\circledR}$ B.

\section{Recommendations}

Ikon ${ }^{\circledR} \mathrm{B}$ should be introduced quickly into the aftermarket as an energysaving alternative to R-22 for existing R-22 air conditioners.

The Department of Energy should establish government beta test sites for Ikon ${ }^{\circledR} \mathrm{B}$ to begin implementation of this valuable energy efficiency technology and to accumulate operational data to support widespread adoption.

Incentives should be provided by electric power distributors, especially where peak electric power prices are high, to install $\mathrm{Ikon}^{\circ} \mathrm{B}$ in place of R-22 to lower peak summer electricity (the most expensive electricity) use. Lowering peak demand sufficiently can also eliminate the need to build new power plants. 
Ikon ${ }^{\circledR} \mathrm{B}$ should be introduced into new R-22 equipment as an alternative to R-410A. The new R-22 equipment can most likely be sold less expensively than new R-410A equipment, with as good or better energy efficiency and lower atmospheric impact.

Eventually, air conditioning equipment should be designed specifically for Ikon ${ }^{\circledR} \mathrm{B}$ to take maximum advantage of its energy efficiency.

\section{References}

1. R. N. Haszeldine, Nature 168, 1028 (1951).

2. Hartgraves, G. A. and Burton, D. J., "The Preparation and Allylation of Difluoromethylcadmium," J. Fluorine Chem. 39, 425-430 (1988).

3. Miller, W. T., Bergman, E., and Fainberg, A. H., "Perfluoroalkylzinc Compounds I. The Preparation and Properties of Perfluoroalkylzinc Halides," J. Am. Chem. Soc. 79, 4159-4164 (1957). 